\title{
Pengembangan Media Audio Visual untuk Mendukung Pembelajaran Tematik Tema 7 Subtema 2
}

\author{
Rista Karisma1 ${ }^{*}$, Mudzanatun $^{2}$, Prasena Arisyanto ${ }^{3}$ \\ 123 Program Studi Pendidikan Guru Sekolah Dasar FIP, Universitas PGRI Semarang, Indonesia
}

\begin{abstract}
Abstrak
Penelitian dan pengembangan ini bertujuan untuk mendukung pembelajaran tematik tema 7 Indahnya Keragaman di Negeriku subtema 2 Indahnya Keragaman Budaya di Negeriku pembelajaran kedua. Subjek penelitian ini terdiri dari kelas IV SD Negeri Muktiharjo Kidul 01 Semarang sebagai kelas uji coba produk dengan jumlah responden 36 siswa. Penelitian ini menggunakan metodologi penelitian Research and Development (R\&D). Langkah-langkah untuk mengembangkan media interaktif berbasis Macromedia Flash menggunakan prosedur pengembangan model ADDIE (Analysis, Design, Development, Implementation, and Evaluation). Kevalidan media diperoleh dari hasil validasi ahli yang terdiri dari dua ahli media dan dua ahli materi. Hasil yang diperoleh dari ahli media I 97,5\% dan ahli media II 93,75\% .Hasil yang diperoleh ahli materi I 96,25\% dan ahli materi II 97,5\% dengan kriteria "Sangat Layak Digunakan". Kepraktisan media diperoleh melalui angket tanggapan siswa dan guru kelas IV SDN Muktiharjo Kidul 01 Semarang terhadap media interaktif berbasis Macromedia Flash. Hasil angket tanggapan siswa kelas IV SDN Muktiharjo Kidul 01 Semarang 98,61\%. Hasil angket tanggapan guru kelas IV SDN Muktiharjo Kidul 01 Semarang 92,5\% dengan kriteria "Sangat Layak Digunakan". Kesimpulan bahwa media interaktif berbasis Macromedia Flash valid dan praktis digunakan pada tema 7 Indahnya Keragaman di Negeriku subtema 2 Indahnya Keragaman Budaya di Negeriku pembelajaran 2 kelas IV Sekolah Dasar.
\end{abstract}

Keywords:

Pengembangan media, Pembelajaran Tematik, Media Audio Visual berbasis Macromedia Flash.

\section{PENDAHULUAN}

Seiring berkembangnya masa, dunia pendidikan di Indonesia mengalami perkembangan. Perkembangan tersebut tentunya tidak lepas dengan kaitannya pengembangan. Pengembangan yang biasa terjadi dalam pendidikan adalah pengembangan kurikulum, proses pembelajaran, sarana prasarana, dan sebagainya. Dalam pengembangan tersebut, ada satu hal yang perlu diperhatikan dan dijadikan pedoman yaitu fungsi pendidikan itu sendiri. Seperti yang termuat dalam Undang-Undang Nomor 20 tahun 2003 tentang Sistem Pendidikan Nasional (UUSPN) Bab II, Pasal 3. Pengembangan pendidikan harus selalu disesuaikan dengan perkembangan zaman seperti di era globalisasi ini. Pada era globalisasi ini, Ilmu Pengetahuan dan Teknologi (IPTEK) memiliki peran penting dalam dunia pendidikan. Tidak hanya dalam pendidikan, tetapi juga di masyarakat. Ilmu Pengetahuan dan Teknologi membantu mempermudah pekerjaan manusia pada segala bidang kehidupan. Seperti Teknologi Informasi dan Komunikasi (TIK) yang bermanfaat dalam salah satu bidang, yaitu bidang pendidikan.

\footnotetext{
* Corresponding author. 
(Hamalik dalam Arsyad, 2015: 2), menjelaskan bahwa perkembangan ilmu pengetahuan dan teknologi semakin mendorong upaya-upaya pembaruan dalam pemanfaatan hasil-hasil teknologi dalam proses belajar. Para guru dituntut agar mampu menggunakan alat-alat yang dapat disediakan oleh sekolah, dan tidak tertutup kemungkinan bahwa alat-alat tersebut sesuai dengan perkembangan dan tuntutan zaman.

Guru sekurang-kurangnya dapat menggunakan alat yang murah dan efisisen yang meskipun sederhana dan bersahaja, tetapi merupakan keharusan dalam upaya mencapai tujuan pengajaran yang diharapkan. Di samping mampu menggunakan alat-alat yang tersedia, guru juga dituntut untuk dapat mengembangkan keterampilan membuat media pembelajaran yang akan diguanakannya apabila media tersebut belum tersedia.

(Ain dalam Jurnal Inspirasi Pendidikan: 316) pembelajaran tematik adalah suatu model terapan pembelajaran terpadu mengintegrasikan beberapa mata pelajaran dalam satu kesatuan yang terikat oleh tema. Pembelajaran tematik merupakan suatu usaha memadukan pengetahuan secara komprehensif dan terintegrasi. Pembelajaran terpadu di sekolah dasar membantu mengembangkan pemahamaan siswa berakibat siswa menjadi lebih terlibat dalam pembelajaran. Menurut Wahyuni (2016) pembelajaran tematik merupakan pembelajaran yang didasarkan dari sebuah tema yang digunakan untuk mengaitkan beberapa konsep mata pelajaran, sehingga anak akan lebih mudah memahami sebuah konsep, karena hanya berdasarkan dari satu tema untuk beberapa pelajaran yang diajarkan. Menurut Haji (2015) Pembelajaran tematik adalah pembelajaran yang dirancang berdasarkan tema-tema tertentu, dalam pembelajaran lain pembelajaran tematik adalah pembelajaran terpadu yang menggunakan tema untuk mengaitkan beberapa mata pelajaran sehingga dapat memberikan pengalaman bermakna kepada peserta didik.

Berdasarkan hasil wawancara peneliti berkaitan dengan Tema Indahnya Keragaman di Negeriku subtema Indahnya Budaya Keragaman Budaya di Negeriku dengan Ibu Siti Musyafaah, S.Pd. selaku guru kelas IV SD Negeri Muktiharjo Kidul 01 Semarang dan Ibu Is Sabrina Ayu Sindoro, S.Pd. selaku guru kelas IV SD Negeri Muktiharjo Kidul 02 Semarang mengatakan bahwa pemanfaatan media pembelajaran masih menggunakan benda-benda kongkrit, seperti berupa gambar (gambar rumah adat, kesenian, baju adat dan lain-lain).

Sedangkan dengan Ibu Tiasmika Sari, S.Pd. selaku guru kelas IV SD Negeri Tlogosari Kulon 06 Semarang, dalam pembelajaran guru sudah pernah menggunakan media audio visual sehingga siswa dapat berkonsentrasi dalam memahami materi yang disampaikan. Namun guru belum pernah membuat kreasi media audio visual, tetapi hanya mendownload video yang ada di internet. Hal ini dikarenakan guru merasa lebih praktis dalam menyajikan media pembelajaran.

Menurut Asmara (2015) Proses pembelajaran merupakan keterpaduan proses mengajar dan belajar. Proses mengajar merupakan penyampaian informasi dari fasilitator pengetahuan kepada akseptornya. Selain sebagai penyampai informasi kepada siswa, fasilitator pembelajaran juga sebagai pengatur proses pembelajaran dan lingkungan di dalam kelas. Proses belajar dipengaruhi oleh faktorfaktor internal dan eksternal. Faktor internal seperti sikap, pandangan hidup, perasaan senang dan tidak senang, kebiasaan dan pengalaman pada diri peserta didik. Faktor eksternal merupakan rangsangan dari luar diri siswa melalui indera yang dimilikinya, terutama pendengaran dan penglihatan. Media pembelajaran adalah salah satu contoh faktor eksternal yang dapat dimanfaatkan untuk meningkatkan efisiensi belajar. Hal itu dapat tercapai karena media pembelajaran dapat mengatasi berbagai hambatan, antara lain: hambatan komunikasi, keterbatasan ruang kelas, sikap siswa yang pasif, pengamatan siswa yang kurang seragam, sifat objek belajar yang kurang khusus sehingga tidak memungkinkan dipelajari tanpa media, tempat belajar yang terpencil dan sebagainya. Media pembelajaran menempati posisi yang strategis dalam proses pembelajaran karena menjadi perantara informasi pengetahuan dari guru kepada siswanya. Banyak manfaat yang diberikan media pembelajaran kepada siswa. (Daryanto, 2016: 7-8) menyatakan bahwa media pembelajaran menempati posisi yang cukup penting sebagai salah satu komponen sistem pembelajaran. Tanpa media komunikasi tidak akan terjadi dan proses pembelajaran sebagai proses komunikasi juga tidak bisa berlangsung secara optimal. Media pembelajaran adalah komponen integral dari sistem pembelajaran. Dalam proses pembelajaran, media memiliki fungsi sebagai pembawa informasi dari sumber (guru/pendidik) menuju penerima (siswa/peserta didik). Media pembelajaran digunakan untuk memperjelas penyajian pesan dan informasi agar menarik perhatian siswa sehingga siswa memperhatikan dan mendapat banyak informasi apa yang disampaikan oleh guru. Dalam perkembangannya media pembelajaran mengikuti perkembangan teknologi. Teknologi yang paling tua dimanfaatkan dalam proses belajar adalah percetakan yang bekerja keras atas dasar prinsip mekanis. Kemudian lahir teknologi audio-visual yang menggabungkan penemuan mekanis dan elektronis untuk tujuan pembelajaran. Teknologi audi-visual cara menghasilkannya atau menyampaikan materi dengan menggunakan mesin-mesin mekanis dan elektronik untuk menyajikan pesan-pesan audio dan visual. 
Menurut Khasanah (2017) media berbasis audio visual, media ini merupakan kombinasi audio dan visual atau biasa disebut media pandang dengar. Menggunakan media pembelajaran audio-visual dalam pembelajaran akan dapat lebih optimal penyajian bahan ajar kepada siswa, selain itu media ini dalam batas-batas tertentu dapat juga menggantikan peran dan tugas guru, dalam hal ini, guru tidak selalu berperan sebagai penyaji materi. Tetapi penyajian materi bisa diganti oleh media audio visual maka peran guru bisa beralih menjadi fasilitator belajar, yaitu memberikan kemudahan bagi para siswa untuk belajar. Menurut Setiadarma (2006:21-22), media pembelajaran audio visual adalah teknologi audio visual cara menghasilkan atau menyampaikan materi dengan menggunakan mesin-mesin mekanis dan elektronik untuk menyajikan pesan-pesan audio dan visual. Ciri utama teknologi media audio visual adalah: a) Bersifat linear, b) Menyajikan visual yang dinamis, c) Digunakan dengan cara yang telah ditetapkan sebelumnya oleh perancang/pembuatnya, d) Merupakan presentasi fisik dari gagasan real atau gagasan astrak, e) Dikembangkan menurut prinsip psikologis behaviorisme dan kognitif , f) Berorientasi kepada guru dengan tingkat perlibatan interaktif murid yang rendah

Kemudian Menurut Hamdani (2010:137), prestasi belajar adalah hasil dari suatu kegiatan yang telah dikerjakan, diciptakan, baik secara individual maupun kelompok, prestasi tidak akan pernah dihasilkan selama seseorang tidak melakukan kegiatan. Arifin (1988:3) mengemukakan bahwa prestasi belajar memiliki beberapa fungsi utama, antara lain: a) Prestasi belajar sebagai indikator kualitas dan kuantitas pengetahuan yang telah dikuasai anak didik, b) Prestasi belajar sebagai lambang pemuasan hasrat ingin tahu, c) Prestasi belajar sebagai bahan informasi dalam inovasi pendidikan, d) Prestasi belajar sebagai indikator intern dan ekstern darii suatu institusi pendidikan, e) Prestasi belajar dapat dijadikan indikator terhadap daya serap (kecerdasan) anak didik

Beberapa penelitian yang berkaitan dengan pengembangan media audio visual berbasis Macromedia Flash adalah penelitian yang dilakukan oleh Veronica Putu Kusuma dalam penelitiannya yang berjudul "Pengembangan Media Pembelajaran Video Interaktif pada Pembelajaran Tematik Integratif Tema Indahnya Keragaman di Negeriku Kelas IV SDN Kalicari 01 Semarang”. Hasil penelitian tersebut menjelaskan bahwa penelitian dan pengembangan ini menggunakan media pembelajaran berupa video interaktif yang dikembangkan dengan menggunakan software Macromedia Flash 8. Penelitian ini dapat membantu siswa untuk menyerap pelajaran dan siswa lebih tertarik mengikuti pelajaran. Dengan adanya media interaktif dapat membantu guru dalam mengajar pembelajaran tematik. Sedangkan penelitian yang dilakukan oleh Bayu Kalahir Kasumaningtyas dalam penelitiannya yang berjudul "Pengembangan Media Pembelajaran Audiovisual Pada Materi Berbicara mata Pelajaran Bahasa Indonesia Kelas II Sekolah Dasar Islam Lukman Hakim Pakisaji Malang". Hasil penelitiannya menjelaskan bahwa siswa dapat memahami materi pada media audiovisual dengan presentase 92,14\%. Adapun hubungan dengan penelitian yang akan dilakukan yaitu dengan mengambil pijakan konseptual yaitu dengan mengembangkan media audio visual yang berbasis Macromedia Flash. Hal ini penggunaan Macromedia Flash akan meningkatkan konsentrasi siswa dalam pembelajaran. Sehingga siswa dapat lebih berkonsentrasi serta memudahkan siswa dalam memahami materi yang disampaikan oleh guru. Selanjutnya Menurut Arwudarachman (2015) penelitian yang dilakukan oleh Danizar Arwudarachman dalam penelitiannya yang berjudul "Pengembangan Media Pembelajaran Audio Visual untuk Meningkatkan Prestasi Belajar Menggambar Bentuk Siswa Kelas XI". Hasil penelitian tersebut menjelaskan bahwa Pengembangan media pembelajaran audio visual dalam pembelajaran gambar bentuk ditentukan setelah melakukan tahap define, design, dan develop. Tahap define terdiri dari studi kepustakaan dan survei lapangan. Tahap design terdiri dari pemilihan media, pemilihan format, dan penyususnan draf awal. Sedangkan tahap develop terdiri dari validasi ahli, revisi produk 1, uji coba terbatas, revisi produk 2, pemakaian media, dan penulisan laporan.

Berdasarkan latar belakang di atas penulis tertarik untuk melakukan penelitian dengan judul "Pengembangan Media Audio Visual Untuk Mendukung Pembelajaran Tematik Tema 7 Subtema 2 Kelas IV SD Negeri Muktiharjo Kidul 01 Semarang"

Berdasarkan latar belakang masalah, maka dapat diidentifikasi sebagai berikut: 1) Pengembangan media pembelajaran yang efisien dan kreatif belum maksimal, 2) Pembelajaran terkesan membosankan, 3) Waktu pembelajaran yang terbatas menyebabkan semua informasi pembelajaran tidak tersampaikan secara maksimal kepada peserta didik.

Berdasarkan latar belakang dan identifikasi masalah diatas maka yang dibatasi dalam penelitian ini adalah : 1) Pengembangan media audio visual untuk mendukung pembelajaran tematik kelas IV Sekolah Dasar dengan tema 7 Indahnya Keragaman di Negeriku subtema 2 Indahnya Budaya Keragaman Budaya di Negeriku pembelajaran 2. 2) Pengujian terhadap media audio visual yang dibuat dengan bantuan program Macromedia Flash, pada kelompok terbatas. 3)Validasi media audio visual oleh 3 pakar (pakar media pembelajaran dan pakar materi pendidikan dasar).

Berdasarkan Identifikasi masalah dan pembatasan masalah di atas, maka dapat dirumuskan masalah sebagai berikut: Bagaimana pengembangan media audio visual untuk mendukung pembelajaran 
tematik Tema 7 "Indahnya Keragaman di Negeriku" Subtema 2 "Indahnya Budaya Keragaman Budaya di Negeriku" kelas IV Sekolah Dasar?

Berdasarkan rumussan masalah, diperoleh tujuan penelitian sebagai berikut : Pengembangan media audio visual untuk mendukung pembelajaran tematik pada tema 7 Indahnya Keragaman di Negeriku subtema 2 Indahnya Keragaman Budaya di Negeriku pada siswa kelas IV Sekolah Dasar.

\section{METODE PENELITIAN}

Jenis penelitian yang dilakukan peneliti dalam penelitian ini adalah metode penelitian dan pengembangan (research and development). Metode penelitian dan pengembangan atau dalam bahasa Inggrisnya Research and Development adalah metode penelitian yang dapat digunakan untuk menghasilkan produk tertentu dan menguji keefektifan produk tersebut (Sugiyono 2016: 407). Pengembangan media pembelajaran dalam penelitian ini menggunakan pengembangan berdasarkan ADDIE. Model ini terdiri dari lima tahap yaitu Analysis (analisis), Design (perancangan), Development (pengembangan), Implementation (implementasi), dan Evaluation (evaluasi) yang harus dilakukan secara sistematik.

Penelitian dilakukan di SD Negeri Muktiharjo Kidul 01 Semarang pada tanggal 22 Mei 2019 semester genap pada siswa kelas IV SD Negeri Muktiharjo Kidul 01 Semarang.

Teknik pengumpulan data dalam penelitian adalah angket kebutuhan siswa dan guru, angket validasi ahli media dan ahli materi, wawancara dan observasi, angket respon siswa dan guru, dokumentasi.

Angket kebutuhan siswa dan guru, wawancara dan observasi bertujuan untuk mendapatkan informasi kondisi awal siswa, guru serta penggunaan media dalam pembelajaran.

Angket validasi ahli media dan ahli materi bertujuan untuk memberikan penilaian terhadap produk yang dikembangkan. Penilaian diberikan berdasarkan pemikiran yang rasional dan dengan uji coba di lapangan. Pakar ahli media dan ahli materi untuk memberikan penilaian berdasarkan produk yang telah didesain dan memberikan masukan berkaitan dengan perbaikan desain produk. Data yang terkumpul dianalisis dengan cara menghitung rerata skor yang diperoleh. Analisis skor yang digunakan yaitu analisis deskriptif dengan langkah-langkah sebagai berikut:

Data yang diperoleh dari ahli media dan materi berupa data kualitatif yang diubah menjadi data kuantitatif dengan ketentuan sesuai dengan pedoman skor ahli media dan ahli materi, dengan ketentuan dibawah ini:

Tabel 1. Pedoman Pemberian Skor Angket Kevalidan

\begin{tabular}{lcc}
\hline & Keterangan & Skor \\
\hline Sangat Setuju & & 4 \\
Setuju & 3 \\
Tidak Setuju & 2 \\
Sangat Tidak Setuju & 1 \\
\hline
\end{tabular}

Setelah data terkumpul, skor setiap aspek dihitung dari validasi angket respon siswa. Angket respon siswa dan guru berkaitan dengan media pembelajaran dilakukan dengan menjawab ketertarikan siswa terhadap media pembelajaran. Menghitung persentase angka dari analisis data yang dilakukan dengan rumus sebagai berikut:

Persentase = skor total
$100 \%$

Dari persentase yang telah diperoleh kemudian ditransformasikan ke dalam kalimat yang bersifat kualitatif. Skor rata-rata yang berupa kuantitatif dari setiap aspek menjadi nilai kualitatif sesuai dengan kriteria kategori penilaian ideal, range persentase dan kriteria interval adalah sebagai berikut: 
Tabel 2. Skala persentase dan Kriteria Kualitatif

\begin{tabular}{lcc}
\hline \multicolumn{1}{c}{ Persentase Penilaian } & Skala Nilai & Kriteria Interpretasi \\
\hline $81 \%-100 \%$ & 4 & Sangat Layak Digunakan \\
$61 \%-80 \%$ & 3 & Layak Digunakan \\
$41 \%-60 \%$ & 2 & Tidak Layak Digunakan \\
$0 \%-40 \%$ & 1 & Sangat Tidak Layak Digunakan \\
\hline
\end{tabular}

Berdasarkan tabel di atas dapat memberikan makna dalam pengambilan keputusan, digunakan ketetapan sebagai indikator keberhasilan melalui validasi ahli media dan ahli materi.Dokumentasi dalam penelitian ini digunakan untuk mendapatkan dokumen sekolah mengenai siswa, jumlah siswa dan datadata yang diperlukan dalam penelitian.

\section{ANALISIS DAN PEMBAHASAN}

Hasil penelitian yang telah dilakukan yaitu "Pengembangan Media Audio Visual Untuk Mendukung Pembelajaran Tematik Tema 7 Subtema 2 Kelas IV SD Negeri Muktiharjo Kidul 01 Semarang”. Pengembangan ini menggunakan prosedur ADDIE (Analysis, Design, Development, Implementation, Evaluation). Berikut langkah-langkah pengembangan prosedur ADDIE:

1. Analysis (Analisis)

a. Analisis Kompetensi

Tahap ini terlebih dahulu menganalisis tema, subtema, Kompetensi Dasar kemudian setelah itu menentukan indikator pembelajaran.

b. Analisis Kebutuhan Siswa

Angket tersebut berisi pertanyaan mengenai pembelajaran tematik yang dilakukan dan mengenai media pembelajaran yang dibutuhkan.

2. Tahap Perencanaan (Design)

Desain dari media audio visual dibuat untuk membantu guru dalam mengajar tema Indahnya Keragaman di Negeriku subtema Indahnya Keragaman Budaya di Negeriku.

3. Tahap Pengembangan (Development)

Tahap pengembangan memuat hasil kelayakan pengembangan media pembelajaran audio visual berbasis Macromedia Flash. Hasil tersebut didapat dari perhitungan validasi ahli media dan ahli materi pembelajaran.

4. Tahap Implementasi (Implementation)

Tahap implementasi yaitu tahap pengujian media pembelajaran berbasis Macromedia Flash. Pada tahap ini diuji cobakan kepada siswa kelas IV SDN Muktiharjo 01 Semarang. Tahap uji coba media dengan 36 siswa, tahap ini mengarah kepada minat siswa dan tanggapan siswa terhadap media pembelajaran berbasis Macromedia Flash.

5. Tahap Evaluasi (Evaluation)

Berdasarkan evaluasi yaitu dengan melihat hasil penelitian dari ahli media, ahli materi dan respon siswa berdasarkan saran dan masukan yang telah diberikan berdasarkan penilaian yang telah dilakukan.

Deskripsi Hasil Uji Keefektifan

Uji keefektifan media pembelajaran interaktif dilakukan di SDN Muktiharjo Kidul 01 Semarang dengan jumlah 36 siswa. Uji keefektifan dilakukan dengan memberikan angket respon siswa terhadap media pembelajaran. Berikut ini hasil angket respon siswa terhadap media pembelajaran.

Tabel 3. Hasil Respon Siswa Uji Coba Terhadap Media Audio Visual Berbasis Macromedia Flash

\begin{tabular}{lcccc}
\hline \multicolumn{1}{c}{ Aspek Penilaian } & Jumlah Skor & Skor ideal & Persentase (\%) & Kriteria \\
\hline Kemudahan Pemahaman & 68 & 72 & 94 & Sangat Baik \\
Keaktifan dalam belajar & 70 & 72 & 97 & Sangat Baik \\
Ketertarikan & 108 & 108 & 100 & Sangat Baik \\
Penyajian & 180 & 180 & 100 & Sangat Baik \\
\hline
\end{tabular}




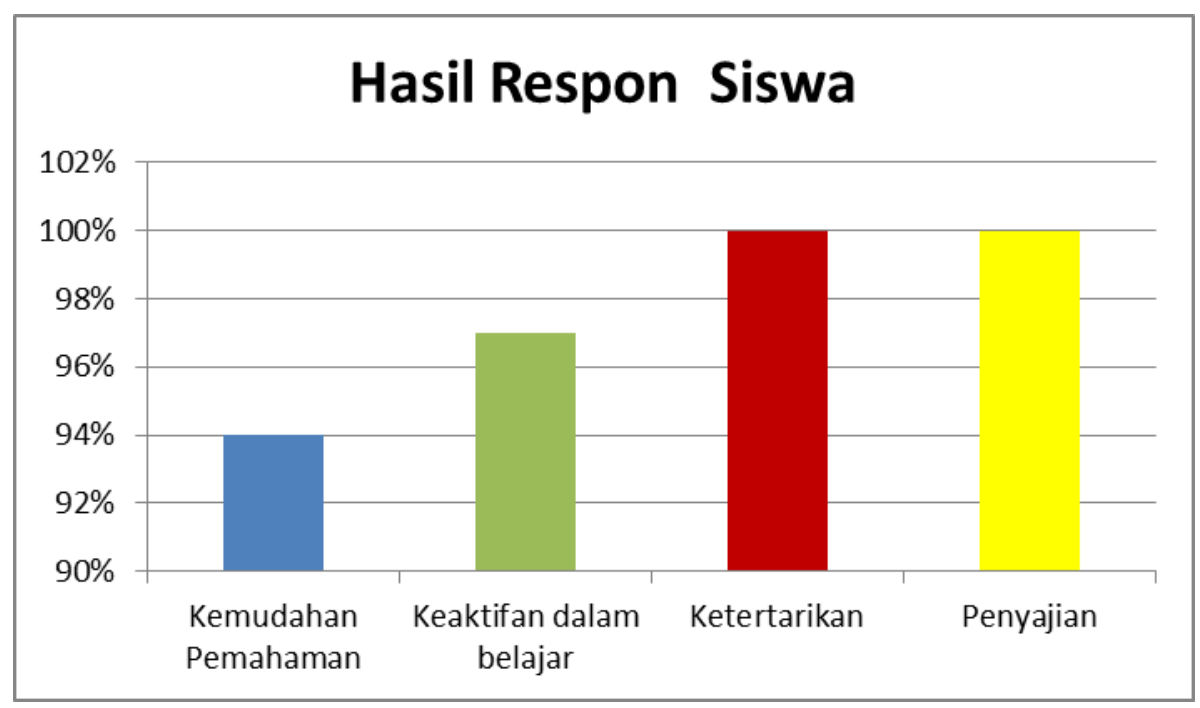

Gambar 1. Hasil Respon Siswa

Berdasarkan hasil analisis respon siswa terhadap media pembelajaran berbasis Macromedia Flash dapat diketahui range nilai dan kriteria setiap indikator:

1. Pembelajaran dengan menggunakan media audio visual berbasis Macromedia Flash 94\% siswa menyatakan bahwa media pembelajaran tersebut dapat memudahkan siswa dalam memahami materi. Sehingga hasil analisis indikator kemudahan pemahaman media audio visual berbasis Macromedia Flash berada di range 81\% - 100\% dengan kriteria "Sangat Baik".

2. Setelah menggunakan media audio visual berbasis Macromedia Flash 97\% siswa menyatakan bahwa media pembelajaran ini dapat membantu siswa aktif dalam belajar. Hasil analisis respon siswa indikator keaktifan belajar berada di range 81\% - 100\% dengan kriteria "Sangat Baik".

3. Setelah belajar dengan menggunakan media audio visual berbasis Macromedia Flash $100 \%$ siswa menyatakan media audio visual berbasis Macromedia Flash menarik perhatian siswa, sehingga siswa merasa lebih semangat dalam belajar. Indikator ketertarikan terhadap media audio visual berbasis Macromedia Flash berada di range 81\% - 100\% dengan kriteria "Sangat Baik".

4. Setelah belajar dengan menggunakan media audio visual berbasis Macromedia Flash $100 \%$ siswa menyatakan media audio visual berbasis Macromedia Flash penyajiannya "Sangat Baik" karena hasil respon siswa terhadap media tersebut berada di range $81 \%$ - $100 \%$.

Berdasarkan hasil analisis respon siswa terhadap media audio visual berbasis Macromedia Flash di atas dapat diketahui nilai rata-rata setiap indikator yaitu 98\% sehingga media audio visual berbasis Macromedia Flash dalam kriteria "Sangat Baik".

\section{KESIMPULAN}

Berdasarkan hasil penelitian dan pengembangan pada penelitian pengembangan media audio visual berbasis Macromedia Flash, maka dapat diambil simpulan bahwa materi yang ada di dalam media ini sesuai dengan tema 7 Indahnya Keragaman di Negeriku subtema 2 Indahnya Keragaman Budaya di Negeriku pembelajaran 2 kelas IV Sekolah Dasar. Media audio visual mudah digunakan sehingga membantu dan mendukung dalam proses pembelajaran tematik di kelas.

Dari hasil yang diperoleh media audio visual berbasis Macromedia Flash "Sangat Layak Digunakan" dalam pembelajaran tematik tema Indahnya Keragaman di Negeriku subtema Indahnya Keragaman Budaya di Negeriku pembelajaran 2 di kelas IV Sekolah Dasar.

\section{DAFTAR PUSTAKA}

Ain, Nurul dan Maris Kurniawati. 2013. "Implementasi Kurikulum KTSP: Pembelajaran Tematik di Sekolah Dasar". Jurnal Inspirasi Pendidikan Unversitas Kanjuruan Malang. Langsung diakses di http://ejournal.unikama.ac.id/index.php/jrninspirasi/article/download/373/148/.

Akbar, Sa’dun, dkk. 2016. Implementasi Pembelajaran Tematik di Sekolah Dasar. Bandung: Rosda. 
Arifin, Zainal. 1988. Evaluasi Instruksional Prinsip-Teknik-Prosedur. Bandung : Remaja Rosdakarya.

Arsyad, Azhar. 2016. Media Pembelajaran. Jakarta: PT Raja Grafindo Persada.

Arwudarachman, Danizar, Wayan Setiadarma, Marsudi. 2015. Pengembangan Media Pembelajaran Audio Visual untuk Meningkatkan Prestasi Belajar Menggambar Bentuk Siswa Kelas XI. Jurnal Pendidikan Seni Rupa, Vol. 3 No. 3 Tahun 2015, Hal. 237-243. Tersedia Pada: https://media.neliti.com/media/publications/249904-pengembangan-media-pembelajaranaudio-vi-8f523b1c.pdf.

Asmara, Anjar Purba. 2015. Pengembangan Media Pembelajaran Berbasis Audio Visual tentang Pembuatan Koloid. Jurnal Ilmiah Didaktika Vol. 15 No. 2 Hal. 156-178. Tersedia Pada: https://jurnal.ar-raniry.ac.id/index.php/didaktika/article/view/578/481.

Astuti, Dwi. 2006. Teknik Membuat Animasi Profesional Menggunakan Macromedia Flash 8. Yogyakarta: C.V ANDI OFFSET.

Daryanto. 2016. Media Pembelajaran. Yogyakarta: Gava Media.

Haji, Sun. 2015. Pembelajaran Tematik yang Ideal di SD/MI. STITNU Al Hikmah Mojokerto Vol. III No. 1 Hal. 56-69. Tersedia Pada: https://www.researchgate.net/publication/307776596_PEMBELAJARAN_TEMATIK_YANG_IDEAL _DI_SDMI.

Hamdani. 2011. Strategi Belajar Mengajar. Bandung: CV. Pustaka Setia.

Khasanah, Dwi Risna Sifaul. 2017. Pengembangan Media Pembelajaran Audio Visual pada Materi Volume Kubus dan Balok Siswa Kelas 5 SDN Krecek 1 Kecamatan Badas Kabupaten Kediri Tahun Ajaran 2016/2017. Simki-Pedagogia Vol. 01 No. 07 Hal. 1-9. Tersedia Pada: http://simki.unpkediri.ac.id/mahasiswa/file_artikel/2017/bf0c6e7a89804144152164e50aec246f .pdf.

Setiadarma, Wayan. 2006. Produksi Media Pembelajaran. Surabaya: Unesa University Press.

Setyosari, Punaji. 2013. Metode Penelitian dan Pengembangan. Jakarta: Prenadamedia Group.

Sudjana, Nana dan Ahmad Riva'i. 2013. Media Pengajaran. Bandung: 2013: Sinar Baru Algensindo.

Sugiyono. 2016. Metode Penelitian Pendidikan Pendekatan Kuantitatif, Kualitatif, dan R\&D. Bandung: Alfabeta.

Wahyono, Teguh. 2006. 36 Jam Belajar Komputer Animasi dengan Macromedia Flash 8. Jakarta: PT Elex Media Komputindo.

Wahyuni, Hermin Tri, Punaji Setyosari, Dedi Kuswandi . 2016. Implementasi Pembelajaran Tematik Kelas 1 SD. Edcomtech Vol. 1, No. 2, Hal. 129-136. Tersedia Pada: http://journal2.um.ac.id/index.php/edcomtech/article/view/1799. 